\title{
ELEMEN PEMBENTUK MAKNA PADA SEBUAH INTERIOR ARSITEKTUR
}

\author{
Dila Hendrassukma \\ School of Design Jurusan Desain Interior Universitas Bina Nusantara, \\ Jln. K.H. Syahdan No.9, Palmerah, Jakarta Barat 11480 \\ justdila@gmail.com
}

\begin{abstract}
Along with the increasing needs of the community, also increasing the need for space to accommodated those needs. With limited space available nowadays, it is not uncommon to change the old buildings' function as a place to meet the social growing need of the space. However, it is must be remembered by architects and interior architects when changing the functions of a space that the old space has its own histories and particular meaning to people who had ever occupied it. Those histories and meanings should be included in the creation of the new function. Article gives and describes elements that need to be known in order to understand the sense of a space, such as drawing plans, scale, proportion, movement, transition and access that embodied in the architecture and interior space. Qualitative methods by literature study is used in the making of this article..
\end{abstract}

Kata kunci: space function, interior element, architecture

\begin{abstract}
ABSTRAK
Seiring dengan meningkatnya kebutuhan masyarakat, meningkat pula kebutuhan ruang untuk mengakomodasi kebutuhan tersebut. Dengan keterbatasan lahan pada saat ini, tidak jarang bangunan tua diubah fungsinya untuk memenuhi kebutuhan masyarakat akan tempat baru. Namun harus diingat oleh para arsitek dan desainer interior ketika mengubah fungsi sebuah ruang bahwa ruang lama tersebut mempunyai sejarah dan makna tersendiri bagi mereka yang pernah menempati. Makna serta sejarah tersebut harus diikutsertakan dalam perancangan fungsi baru. Artikel menjelaskan elemen yang perlu diketahui untuk memahami makna sebuah ruang, seperti gambar perencanaan, skala, proporsi, transisi, gerakan dan akses yang terkandung dalam sebuah arsitektur dan interior. Metode yang dipakai dalam penulisan artikel adalah metode kualitatif dengan tipe studi literatur.
\end{abstract}

Kata kunci: makna ruang, elemen interior, arsitektur 


\section{PENDAHULUAN}

Sebuah tempat merupakan sebuah ruang atau area yang mengandung makna. Makna tersebut tidak jarang berasal dari sejarah yang terjadi di ruang tersebut. Sejarah yang terkandung dalam ruang itu dapat diketahui oleh khalayak luas atau hanya merupakan pengalaman pribadi. Sebagai contoh, Trafalgar Square di London, Inggris, menimbulkan rasa yang dapat dipahami masyarakat luas, yaitu kekuasaan, dikarenakan tempat tersebut merupakan daerah kekuasaan raja pada zamannya. Namun lain halnya dengan perasaan yang didapat sewaktu kita melintasi jalanan atau taman bermain tempat kita berjalan atau bermain setiap hari sewaktu kita kecil. Perasaan atau makna itu hanya dapat dirasakan oleh kita pribadi yang mempunyai kenangan sendiri di tempat tersebut.

Memahami makna dan konteks dari sebuah ruang pada sebuah bangunan sangatlah penting dalam proses mendesain. Seorang arsitek akan sering turut serta dalam menciptakan makna dari sebuah tempat. Namun tidak demikian halnya untuk seorang desainer interior. Peran dari desainer interior adalah meniupkan nafas baru pada sebuah ruang atau tempat yang telah memiliki makna dan sejarah yang dikarenakan faktor-faktor sosial, ekonomi, fashion, atau berganti kepemilikan, ruang tersebut membutuhkan identitas baru. Dalam tercapainya transformasi tersebut desainer interior harus mengerti serta paham akan kontribusi dari sejarah bangunan tersebut dan menggunakannya dalam membuat sebuah proposal desain yang mengerti, menghargai, menghormati serta terlibat dalam dialog dengan bangunan yang sudah ada.

Terdapat banyak alasan yang baik untuk menggunakan bangunan tua sebagai sebuah fungsi baru daripada menghancurkan bangunan tersebut dan membangunnya dari awal. Pada kenyataannya dibutuhkan modal yang mungkin cukup besar untuk mengganti material serta energi lama yang telah terdapat pada bangunan lama tersebut. Namun dengan menggunakan bangunan lama kita dapat memperkaya pengalaman kita dengan menghubungkan masa lalu, masa kini, dan masa yang akan datang.

Dalam bangunan-bangunan lama selalu terdapat bukti-bukti akan bentuk-bentuk, material yang digunakan, keahlian dan detail konstruksi yang ada pada jamannya, dan juga tambahan-tambahan dan perubahan yang terjadi sejalannya bangunan tersebut berdiri. Hal-hal tersebut merupakan sumber kekayaan dan semangat tersendiri bagi desainer sewaktu membuat skema desain baru. Wujud dan proporsi ruang, bentuk dan penenmpatan bukaan jendela, serta struktur berkontribusi dalam menciptakan makna sebuah ruang. Sebuah hal yang mana merupakan kewajiban seorang desainer interior untuk mengenali makna tersebut dan menggunakan kualitas dan peluang yang ditawarkan.

\section{PEMBAHASAN}

Pembahasan berikut merupakan faktor-faktor, dan istilah yang digunakan untuk menggambarkannya, yang menjadi pedoman penting dalam membuat dan mengerti akan sebuah interior arsitektur. Faktor-faktor ini dapat digunakan untuk mengekspresikan karakter dan kualitas dari sebuah interior, dan digunakan baik secara individual ataupun sebagai kombinasi, serta akan menciptakan suasana serta kepribadian akan tempat tersebut.

\section{Bidang Perencanaan}

Bidang perencanaan merupakan elemen atau faktor yang paling mendasar dalam interior arsitektur. Sebuah bidang perencanaan merupakan gambar dua dimensi yang dapat menggambarkan bagaimana rencana lantai, dinding, dan langit-langit dalam membentuk sebuah ruang. Bidang perencanaan tersebut juga dibuat lebih detil dengan menyertakan rencana penempatan pintu-pintu, tangga, serta elemen interior lainnya seperti furnitur. 


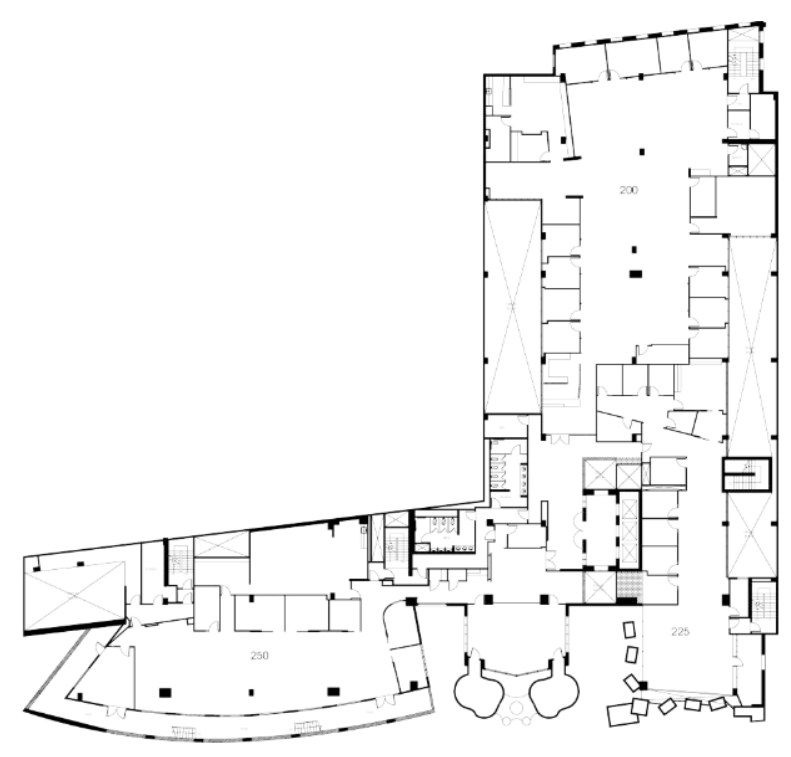

Gambar 1. Floor Plan kantor Google di Venice

Gambar dua dimensi ini membawa keterangan-keterangan seperti material yang digunakan, tekstur, dan kualitas warna yang dibutuhkan, serta bagaimana mengontrol segi akustik dan pencahayaan. Dengan adanya bidang perencanaan, setiap bagian dari elemen interior akan mendapat perhatian secara langsung termasuk jalur-jalur dan pergerakan cahaya, udara, dan suara.

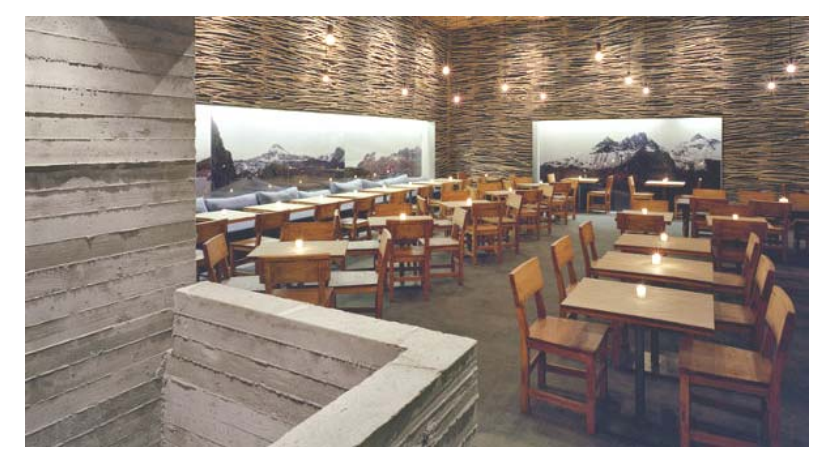

Gambar 2. Sebuah bidang perencanaan akan memudahkan dalam penyusunan meja dan kursi pada sebuah restoran.

\section{Skala}

Faktor kedua adalah skala. Istilah skala mempunyai dua arti bagi seorang desainer. Arti yang pertama berhubungan dengan metode menggambar bangunan. Gambar bangunan tersebut diperkecil dari ukuran sebenarnya agar dapat digambar di kertas yang kita gunakan. Untuk melakukan ini kita dapat menggunakan skala. Seluruh bagian yang di desain diperkecil secara visual dengan menggunakan rasio atau perbandingan. Sebagai contoh, jika kita ingin menggambar plan dari sebuah lokasi proyek, skala yang digunakan adalah 1:200 atau 1:500. Hal itu berarti setiap elemen yang tergambar merupakan satu per dua ratus atau satu per lima ratus dari ukuran aslinya. Sewaktu kita ingin menggambar sesuatu yang lebih kecil ukurannya, seperti detil dari sebuah lemari, kita dapat mengunakan skala 1:5 ataupun ukuran sebenarnya. 
Arti kedua dari skala adalah bagaimana hubungan ukuran sebuah benda dengan benda lain. Mengingat bahwa seorang desainer interior mendesain sebuah tempat untuk manusia beraktivitas didalamnya, maka perbandingan yang digunakan sebagai 'benda lain' adalah ukuran manusia tersebut, yang mana dalam pelaksanaannya dapat disebut sebagai 'human scale'. Maka, jika mendapati sebuah tempat atau benda yang nyaman dan sesuai dengan dimensi kita sebagai manusia, kita dapat menyebut tempat atau benda tersebut mempunyai 'human scale'.

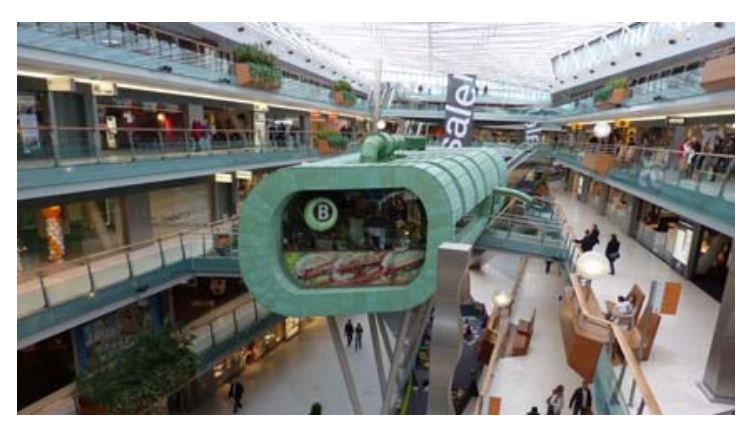

Gambar 3. Villa Arena Furniture Shopping Mall.

\section{Proporsi}

Jika skala menjelaskan ukuran dari sebuah elemen dibandingkan dengan sebuah standar ukuran, maka proporsi mengarah pada hubungan dimensi dari elemen-elemen desain -satu dengan yang lain atau satu dengan keseluruhan. Mata manusia mengenali kualitas dari sebuah ruang dengan proporsi dalam kaitannya dengan ukuran dirinya. Langit-langit yang rendah di ruangan yang besar akan terasa menekan. Namun ketika ruangan tersebut diperkecil dengan langit-langit yang sama ketinggiannya, maka akan memungkinkan untuk ruangan tersebut terasa lebih nyaman. Ruang-ruang yang sangat tinggi, seperti yang terdapat di katedral dan bangunan publik lainnya, dapat menghasilkan rasa kagum dan gembira.

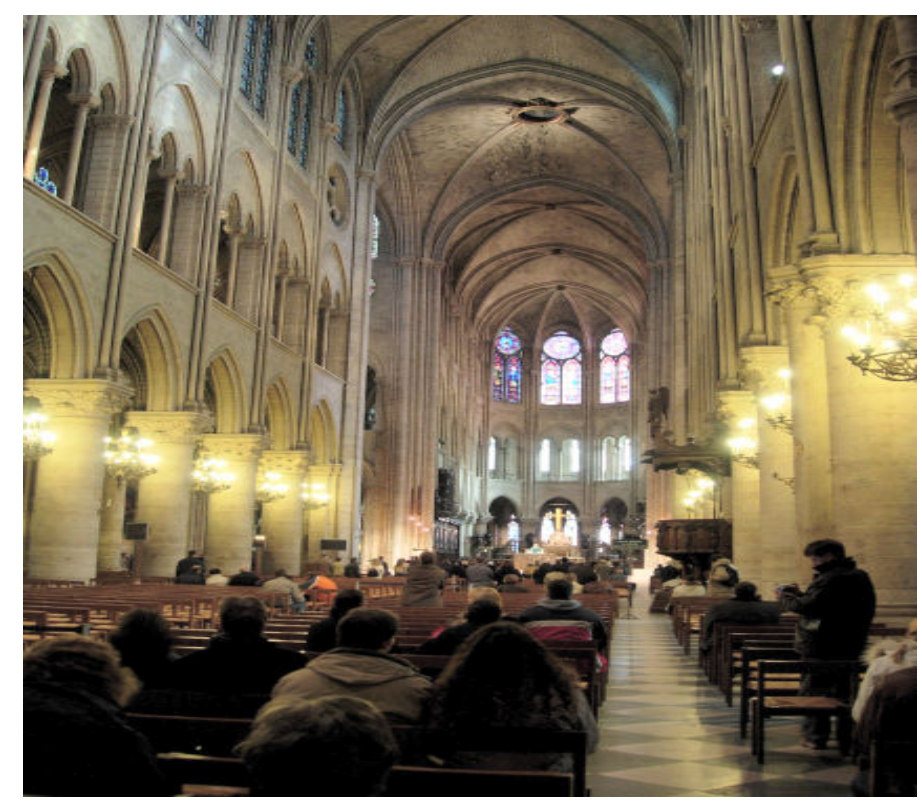

Gambar 4. Ceiling tinggi yang terdapat di Cathedral of Notre Dame de Paris 
Hubungan denah sebuah bangunan dengan tingginya tidak hanya penting dalam hal spasial, namun juga penting kaitannya dengan kualitas cahaya alami yang masuk ke dalam bangunan tersebut. Contoh dari kurang proporsionalnya luas dan tinggi sebuah area adalah ruang-ruang kantor dengan denah terbuka pada gedung bertingkat. Terbatasnya jarak dari lantai ke langit-langit membuat cahaya alami tidak dapat menyinari ruang yang besar tersebut secara menyeluruh. Hal tersebut mengakibatkan perlunya pemakaian cahaya buatan atau lampu secara permanen.

Pentingnya skala dan proporsi telah dihargai selama ribuan tahun dan telah menjadi subyek pengamatan dan teori oleh banyak arsitek, seniman, serta para filsuf untuk menemukan dan mengembangkan sebuah sistem universal yang akan menjamin kesempurnaan visual pada bangunan dan barang artefak. Sistem-sistem yang ditemukan tersebut berkisar mulai dari sistem yang sepenuhnya matematika murni seperti Fibonacci Sequence dan Golden Section (sistem proporsi yang digunakan pada jaman Yunani kuno) sampai dengan Vitruvian Man karya Leonadro da Vinci. Pada tahun 1974, arsitek modern dari Swiss, Le Corbusier menngajukan sebuah sistem yang berjudul The Modulor yang menyatukan sistem proporsi antropometri dan matematika.

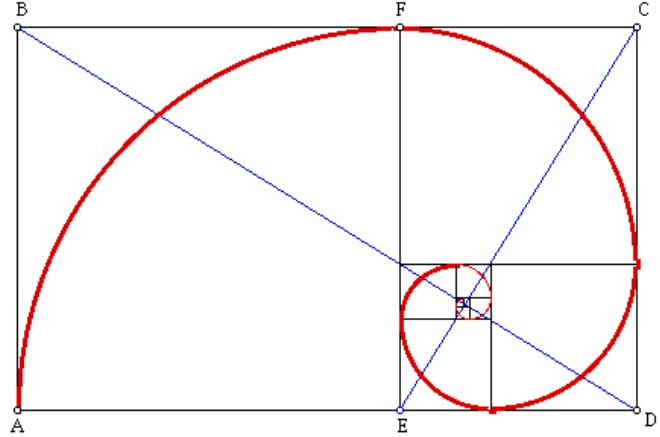

Gambar 5. Golden Section

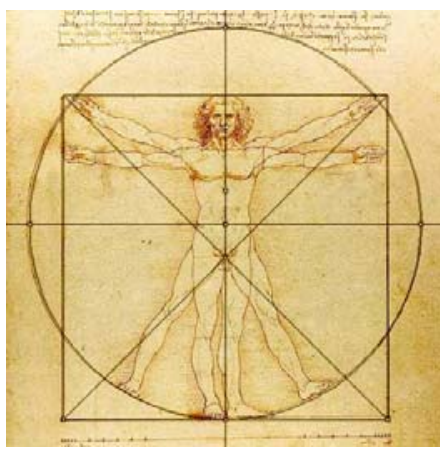

Gambar 6. Vitruvian Man

Sulit untuk memastikan sampai sejauh mana sistem-sistem proporsi ini digunakan sebagai bagian dari proses kreatif dalam mendesain, dan seberapa banyak yang dihasilkan dari analisa desain yang berfokus pada hal-hal seperti kuil Yunani klasik dan susunan spiral pada kerang. Namun informasi ini tidak terhingga nilainya dalam menciptakan sebuah ruang, proses dan produk yang sesuai dengan proporsi dan pergerakan tubuh manusia.

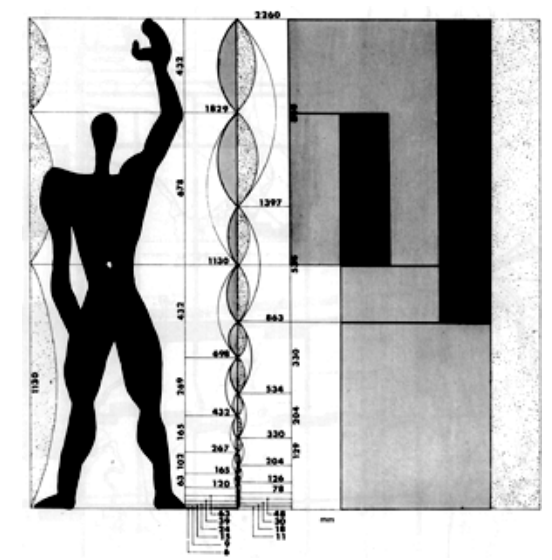

Gambar 7. The Modulor 


\section{Pergerakan}

Faktor selanjutnya adalah pergerakan atau movement. Seorang desainer interior tidak boleh mengesampingkan potensi kenikmatan yang dihasilkan dari gerakan nyata melalui sebuah ruang. Tangga, ramp, eskalator dan lift dapat memainkan perannya masing-masing dalam memindahkan penggunanya melalui ruang-ruang. Alat-alat tersebut juga dapat sekaligus menciptakan kemungkinan akan sebuah pencerahan. Tangga dapat hanya berupa alat penunjang pergerakan yang paling sering ditemukan dalam sebuah bangunan. Namun secara fisik sebuah tangga dapat pula menghadirkan arti lain yaitu sebagai sebuah benda seni dan sebagai alat penghubung bentuk-bentuk serta material dari setiap lantai yang dihubungkannya.

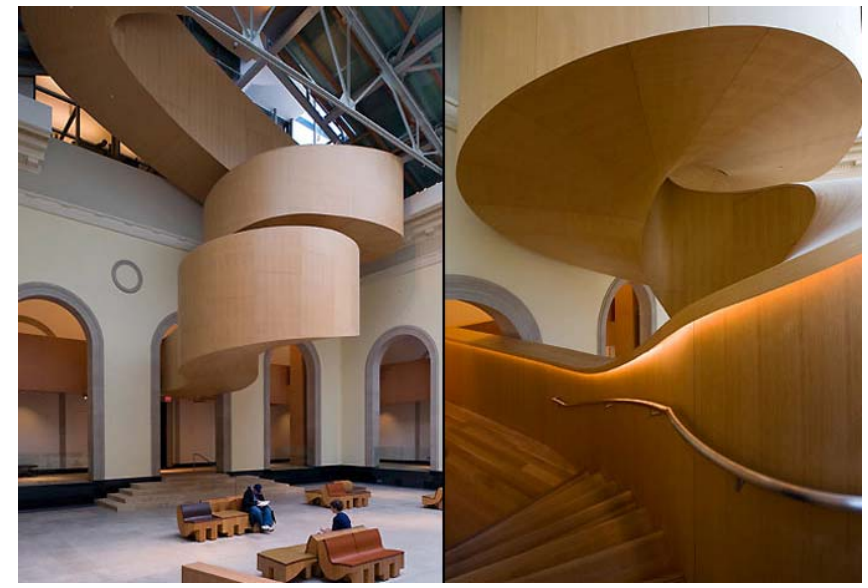

Gambar 8. Tangga di Art Gallery of Ontario, karya Frank ’O Gehry

Le Corbusier berkata bahwa 'tangga memisahkan, ramp menyatukan'. Hal tersebut benar adanya bahwa ramp membawa kemungkinan akan arus atau aliran serta trasisi halus yang mana sulit diwujudkan pada pergerakan atau perpindahan menggunakan tangga. Hal yang penting mengenai ramp adalah bahwa untuk dapat digunakan dengan mudah ramp harus landai, namun berarti diperlukan jarak rentang yang panjang untuk mengakomodasikannya dan hal ini seringkali sulit dilaksanakan di dunia nyata. Pada kasus Richard Meier, arsitek kontemporer yang menggunakan ramp lebih konsisten dibandingkan dengan arsitek kontemporer lainnya, mengambil cukup banyak bagian bangunan pada salah satu karyanya, Museum of Contemporary Art di Barcelona, untuk mengakomodasi ramp nya yang landai.

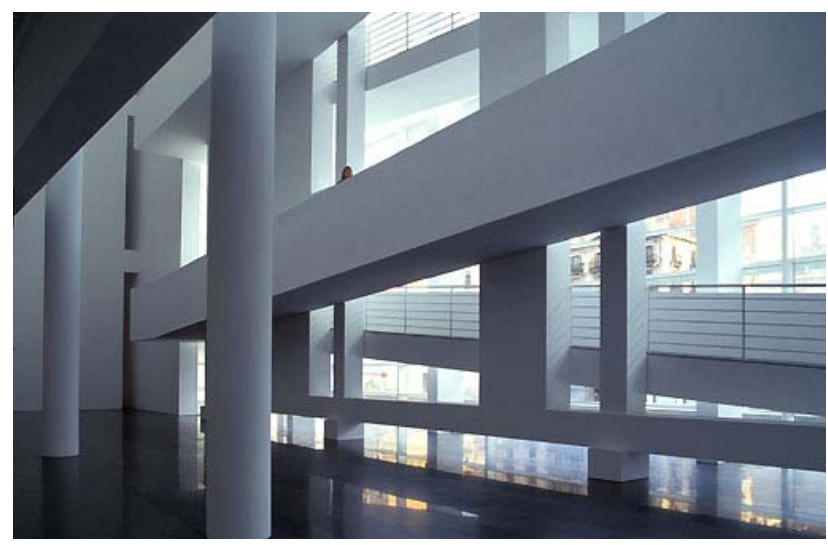

Gambar 9. Ramp pada Museum of Contemporary Art, Barcelona 
Beberapa tahun sebelumnya Frank Lloyd Wright menerapkan pendekatan yang sedikit berbeda sewaktu mendesain Guggenheim Museum di New York dengan membelokan ramp menjadi bentuk spiral yang mengelilingi ruang kosong di tengahnya. Dalam melakukan hal tersebut, Le Corbusier menciptakan sebuah sistem yang membuat ramp berfungsi sekaligus sebagai ruang galeri dan sistem akses, dan menghasilkan sebuah bangunan yang menjadi ikon di kota New York.

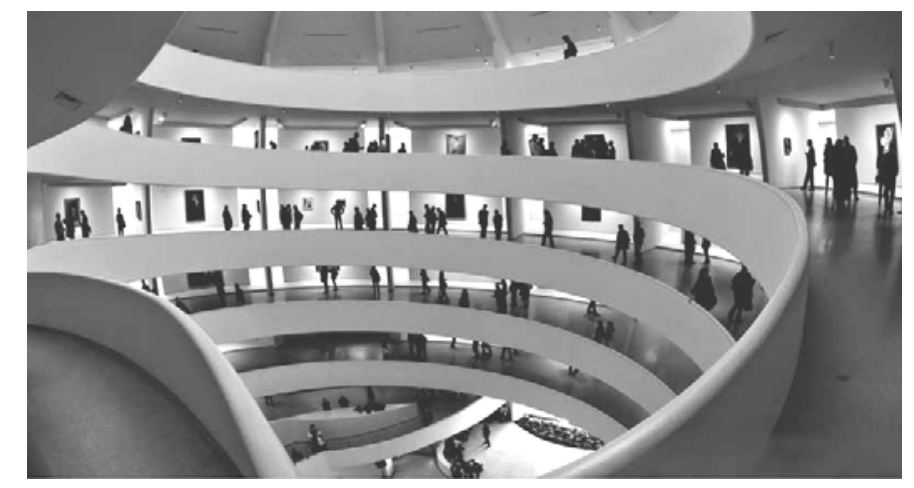

Gambar 10. Ramp yang sekaligus menjadi ruang galeri di Museum of Modern Art, New York

Eskalator atau tangga jalan dan lift bekerja dengan cara yang sedikit berbeda. Lift kaca, terutama yang berada di permukaan luar bangunan, tidak lagi merupakan hal baru tapi masih mempunyai daya tarik yang kuat. Dalam banyak hal eskalator menyediakan perpaduan antara lift, ramp, dan tangga karena lintasannya yang bergerak sendiri. Namun seringkali bentuk dan materialnya, serta transisi di awal dan akhir penggunaannya kurang memuaskan pengalaman dari penggunanya.

\section{Transisi}

Faktor kelima dalam menciptakan dan memahami sebuah interior arsitektur adalah transisi. Area yang menghubungkan dua ruang merupakan area transisi atau perpindahan. Area transisi ini bukan merupakan ruang negatif atau ruang tidak bermakna. Sebaliknya, area transisi tersebut mampu mendukung karakternya sendiri dan menciptakan sebuah peristiwa di dalamnya. Dengan memikirkan bentuk, proporsi, pencahayaan, dan suasana akan peristiwa tersebut, kita dapat menjadikan area transisi itu menjadi ruang sosial ataupun ruang pribadi, sebuah ruang untuk menyambut peristiwa selanjutnya atau tempat untuk mengingat hal yang telah berlalu.

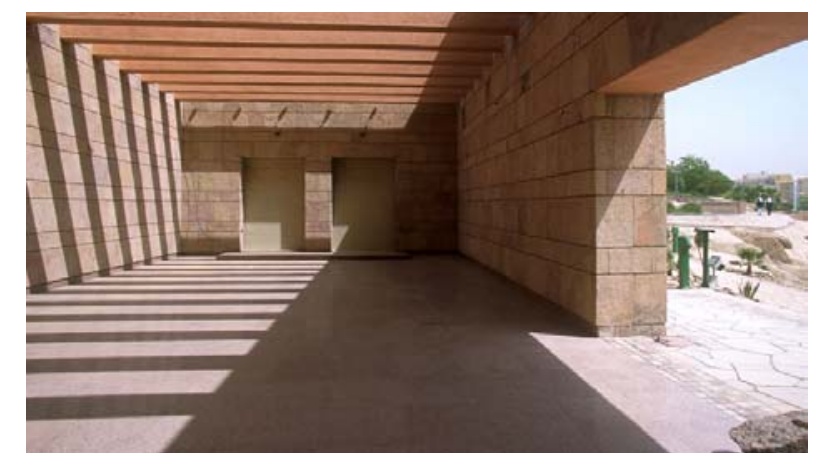

Gambar 11. Ruang transisi antara ruang galeri dengan area luar pada Nubian Museum di Mesir. 
Untuk menciptakan ruang transisi tersebut banyak hal yang harus dipertimbangkan dan diputuskan. Arah, ukuran bukaan, serta penggunaan pintu sebagai pembatas adalah beberapa diantaranya. Yang dapat membantu untuk menentukan desain ruang transisi adalah hubungan ruang tersebut dengan fungsi ruang serta bangunan, brief dari desain bangunan itu sendiri, serta pendekatan konseptual desainer yang merancangnya.

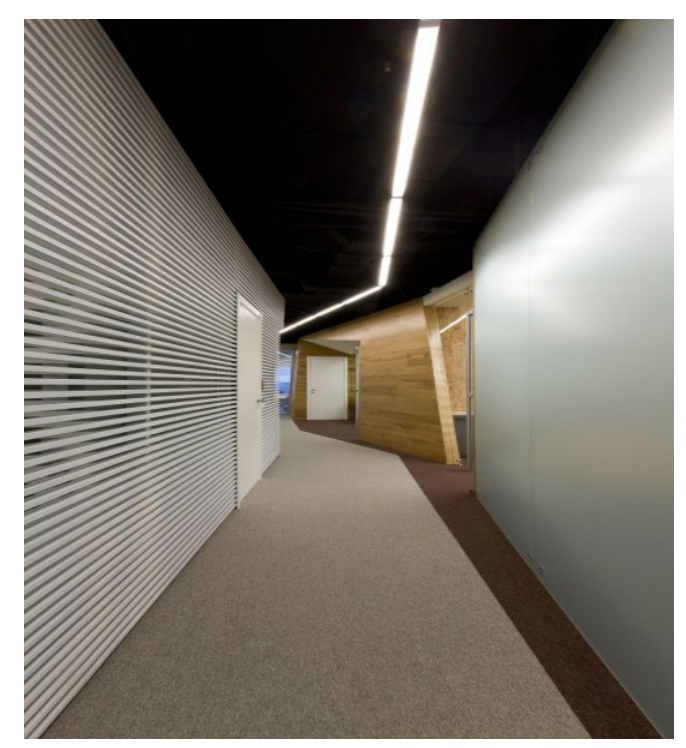

Gambar 12. Koridor pada kantor yang menghubungkan ruang satu dengan yang lain

\begin{abstract}
Akses
Jika faktor-faktor yang dibahas sebelumnya menyangkut spasial dan pergerakan di dalam interior, maka faktor keenam ini menekankan akses atau bagaimana cara mencapai interior bangunan tersebut. Sampai beberapa waktu lalu, bangunan hanya di desain untuk mereka yang baik secara fisik. Para perancang tersebut melupakan para orang tua, anak kecil, serta para penyandang cacat atau mereka yang memiliki keterbatasan fisik. Pintu, tangga, bukaan atau akses yang sempit merupakan tantangan nyata untuk mereka. Pada akhirnya, setelah banyaknya kampanye yang dilakukan oleh yayasan serta organisasi-organisasi, masalah ini menjadi kewajiban bagi para desainer, pemilik bangunan dan para profesional lainnya untuk menciptakan aksesibilitas serta kegunaannya untuk setiap lapisan masyarakat. Pada saat ini hampir di setiap pusat perbelanjaan telah dihadirkan toilet khusus pengguna kursi roda yang luasannya dapat mengakomodasi kursi roda mereka. Banyak juga pusat perbelanjaan yang telah menyediakan toilet khusus anak-anak dengan ukuran sanitari yang sesuai dengan ukuran tubuh mereka. Serta hampir di setiap bangunan publik telah disediakan akses ramp untuk mereka yang tidak mampu menaiki anak tangga. Bagaimanapun juga, bangunan yang baik adalah sebuah bangunan yang dapat diakses oleh seluruh tipe fisik manusia, karena sebuah arsitektur diharapkan tidak hanya dapat dinikmati dari luar, namun juga dapat di nikmati 'isi'nya.
\end{abstract}




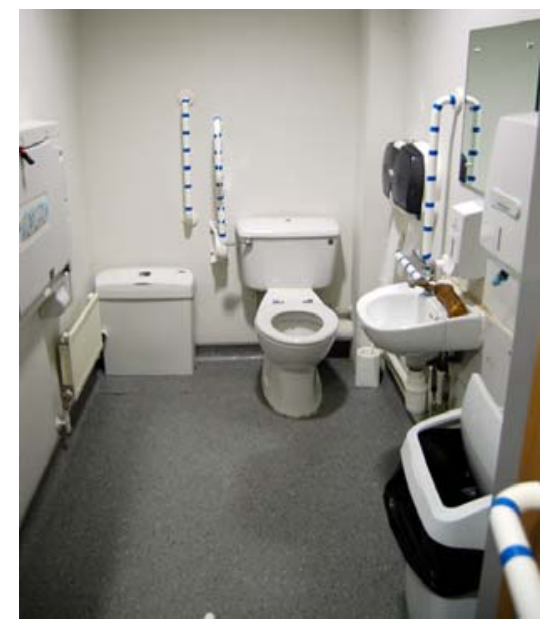

Gambar 13. Toilet penyandang cacat pada salah satu stadion bola di Inggris

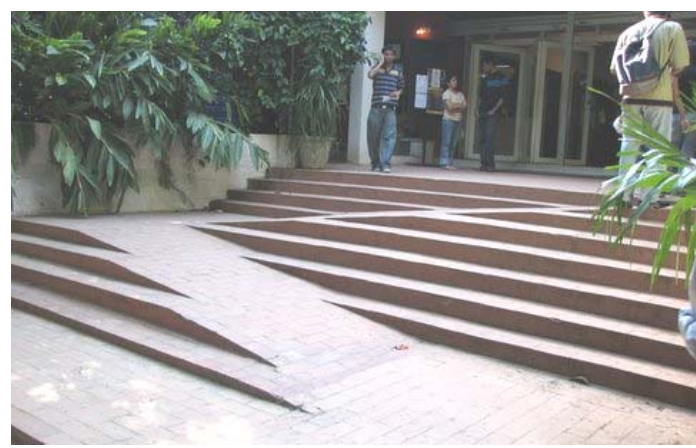

Gambar 14. Ramp yang di desain menyatu dengan tangga pada sebuah bangunan publik

\section{PENUTUP}

Seiring dengan bertambahnya kebutuhan masyarakat, baik itu kebutuhan primer, sekunder ataupun tersier, bertambah pula kebutuhan akan ruang yang dapat mengakomodasi kebutuhankebutuhan tersebut. namun dengan terbatasnya lahan yang ada, tidak jarang bangunan-bangunan lama yang sudah tidak layak pakai ataupun tidak popular lagi dikunjungi berubah fungsinya sebagai tempat baru untuk memenuhi kebutuhan ruang tersebut. Yang perlu diingat oleh para arsitek dan arsitek interior, sewaktu merubah fungsi sebuah ruang dan memasukkan makna baru pada sebuah ruang lama adalah bahwa ruang-ruang atau bangunan-bangunan lama tersebut telah memiliki sejarah serta makna tersendiri untuk masyarakat yang pernah menempatinya, baik secara temporer ataupun permanen. Sejarah serta makna tersebut sebisa mungkin diikut sertakan dalam penciptaan fungsi baru di dalam bangunan itu. Penyertaannya dapat sebagai latar belakang keputusan konsep desain ataupun keputusan fisik desain. Makna dari sebuah interior arsitektur sendiri dapat dipelajari dengan memahami hal-hal seperti elemen-elemen interior. Elemen-elemen tersebut mencakup gambar perencanaan, skala, proporsi benda dan bangunan terhadap sekitarnya, pergerakan manusia di dalamnya, transisi antar ruang, serta akses menuju ruang tersebut. Dengan memahami hal-hal ini dan menerapkannya dengan tepat pada rancangan baru, maka arsitek ataupun desainer interior telah mencoba untuk menghargai makna dan sejarah yang telah ada sebelumnya. 


\section{DAFTAR PUSTAKA}

Brooker, G., \& Stone, S. (2009). Basic Interior Architecture: Elements/ Objects. Ava Publishing SA. Switzerland. ISBN: 2940411107

Coles, J., \& House, N. (2007). The Fundamentals of Interior Architecture. Ava Publishing SA. Switzerland. ISBN: 2-940373-38-8 